\title{
MOUSE BLASTOCYST RE-EXPANSION FOLLOWING PUNCTURE AND TREATMENT WITH INHIBITORS
}

\author{
R. H. GLASS, ${ }^{*}$ T. P. LIN AND JOAN FLORENGE \\ Department of Anatomy, University of Califormia, San Francisco, \\ California 94122, U.S.A.
}

(Received 4th Fune 1973)

The introduction of a pipette or needle into the blastocoele has been used for measurement of the potential difference across the trophoblast (Gamow \& Daniel, 1970; Cross, 1971), for aspiration of fluid (Lutwak-Mann, Boursnell \& Bennett, 1960; Smith, 1970), for removal of a portion of the inner cell mass (Lin, 1969), for injection of teratogens (Lin \& Monie, 1973) and for injection of cells into the blastocyst cavity (Gardner, 1968; Moustafa \& Brinster (1972). Despite temporary distortion following manipulation, the blastocyst exhibits a remarkable ability to regain its original form. Capacity for normal development is also retained in most cases.

Rabbit blastocysts which contracted after microsurgery seldom implanted unless they were allowed to re-expand in culture for $3 \frac{1}{2}$ to $9 \mathrm{hr}$ before transfer (Gardner \& Edwards, 1968). In contrast to conditions in the rabbit, work in our laboratory has shown that transfer of the contracted mouse blastocyst does not limit subsequent development. Possibly this success is dependent upon a very rapid re-expansion of the mouse blastocyst following transfer. The purpose of this study was to determine the time sequence of re-expansion following puncture of the blastocoele. In addition, to determine whether RNA or protein synthesis is required for re-expansion, the effect of actinomycin $\mathrm{D}$ and puromycin on blastocyst re-expansion was evaluated.

Mice of the C57BL/6 or ICR strain were induced to superovulate with sequential injections of PMSG (Sigma) and HCG (APL, Ayerst). Blastocysts were obtained from these animals on the 4th day after mating with either C57BL/6 or ICR males.

For microsurgery, the blastocysts were deposited into a small drop of Brinster's (1963) medium in an 'egg-well' (Lin, 1971) which was covered with mineral oil. Blastocysts were secured for injection by a smooth holder pipette. A bevelled pipette with a sharp tip (the orifice was approximately 2 to $4 \mu \mathrm{m}$ in diameter) held in a Leitz micromanipulator, was inserted through the trophoblast into the blastocoele and quickly withdrawn. Care was taken to avoid the inner cell mass.

Immediately after puncture, groups of five to fourteen blastocysts were placed in a microdrop of approximately $0.02 \mathrm{ml}$ Brinster's medium which was covered by light-weight paraffin oil equilibrated with the medium and $5 \%$

* Present address: Department of Obstetrics and Gynecology, Yale University School of Medicine, 333 Cedar Street, New Haven, Connecticut, 06510, U.S.A. 
$\mathrm{CO}_{2}$. Other punctured blastocysts were placed in microdrops of either $0 \cdot 1 \mu \mathrm{g}$ actinomycin $\mathrm{D} / \mathrm{ml}$ (Calbiochem) or $50 \mu \mathrm{g}$ puromycin dihydrochloride $/ \mathrm{ml}$ (Nutritional Biochemicals Corporation). The actinomycin was diluted in distilled water to a concentration of $330 \mu \mathrm{g} / \mathrm{ml}$, then diluted to final concentration in Brinster's medium. The puromycin was diluted from powder form in Brinster's medium.

All preparations were gassed with $5 \% \mathrm{CO}_{2}$ in air for $30 \mathrm{~min}$ and incubated at $37^{\circ} \mathrm{C}$ for intervals of $1,4,8$ or 20 to $23 \mathrm{hr}$. Following incubation, preparations were viewed with a light microscope and then either discarded or returned to the incubator for regassing and further culture.

On the basis of size and configuration, each blastocyst was assigned to one of four categories: 1 , degenerated; 2 , completely collapsed; 3 , blastocoele partially re-expanded, or 4 , blastocoele fully re-expanded. The results of the study were not further clarified by subdivision of Category 3 .

Table 1. Mouse blastocyst re-expansion following puncture and culture in Brinster's medium or in inhibitors

\begin{tabular}{|c|c|c|c|c|c|c|}
\hline \multirow{2}{*}{ Treatment } & \multirow{2}{*}{$\begin{array}{c}\text { Time } \\
(h r)\end{array}$} & \multirow{2}{*}{$\begin{array}{c}\text { No. of } \\
\text { blastocysts }\end{array}$} & \multicolumn{4}{|c|}{$\%$ Blastocysts } \\
\hline & & & Degenerated & Collapsed & Partial & Full \\
\hline Brinster's & $\begin{array}{r}1 \\
4 \\
8 \\
20 \text { to } 23\end{array}$ & $\begin{array}{r}42 \\
77 \\
68 \\
111\end{array}$ & $\begin{array}{l}0 \\
1 \\
2 \\
1\end{array}$ & $\begin{array}{r}21 \\
13 \\
10 \\
0\end{array}$ & $\begin{array}{r}79 \\
82 \\
56 \\
3\end{array}$ & $\begin{array}{r}0 \\
4 \\
32 \\
96\end{array}$ \\
\hline $\begin{array}{c}\text { Actinomycin } \\
0.1 \mu \mathrm{g} / \mathrm{ml}\end{array}$ & $\begin{array}{r}4 \\
8 \\
20 \text { to } 23\end{array}$ & $\begin{array}{l}44 \\
32 \\
64\end{array}$ & $\begin{array}{r}0 \\
0 \\
100\end{array}$ & $\begin{array}{l}7 \\
0 \\
0\end{array}$ & $\begin{array}{r}86 \\
66 \\
0\end{array}$ & $\begin{array}{r}7 \\
34 \\
0\end{array}$ \\
\hline $\begin{array}{l}\text { Puromycin } \\
50 \mu \mathrm{g} / \mathrm{ml}\end{array}$ & $\begin{array}{r}4 \\
8 \\
20 \text { to } 23\end{array}$ & $\begin{array}{l}27 \\
27 \\
11\end{array}$ & $\begin{array}{r}0 \\
48 \\
100\end{array}$ & $\begin{array}{r}7 \\
38 \\
0\end{array}$ & $\begin{array}{r}89 \\
7 \\
0\end{array}$ & $\begin{array}{l}4 \\
7 \\
0\end{array}$ \\
\hline
\end{tabular}

Within $30 \mathrm{sec}$ of puncture, blastocysts began to contract and both the trophoblast layer and the inner cell mass appeared thicker. Five minutes after puncture, the entire mass of cells was retracted from the zona pellucida, and the blastocoele appeared to be obliterated in almost all blastocysts (Pl. 1, Fig. 1). By focusing through the blastocysts, however, a minimal residual cavity could be identified. Those blastocysts $(<5 \%$ ) which did not collapse following puncture were discarded from the experiment. The zona did not contract during the initial 5 min following puncture but no attempt was made to measure changes in the size of the zona at later intervals. Cole (1967) noted a slow contraction of the zona over a 2 -hr period in association with spontaneous contractions of the blastocyst.

Re-expansion occurred in an orderly time sequence (PI. 2, Figs 2 and 3). Neither of the two inhibitors blocked re-expansion though both eventually destroyed the embryos (Table 1).

The mechanisms governing the fluid accumulation which transforms a morula into a blastocyst are unknown. There is evidence of active transport of ions across the blastocyst wall (Lutwak-Mann et al., 1960; Smith, 1970) which 
PLATE 1

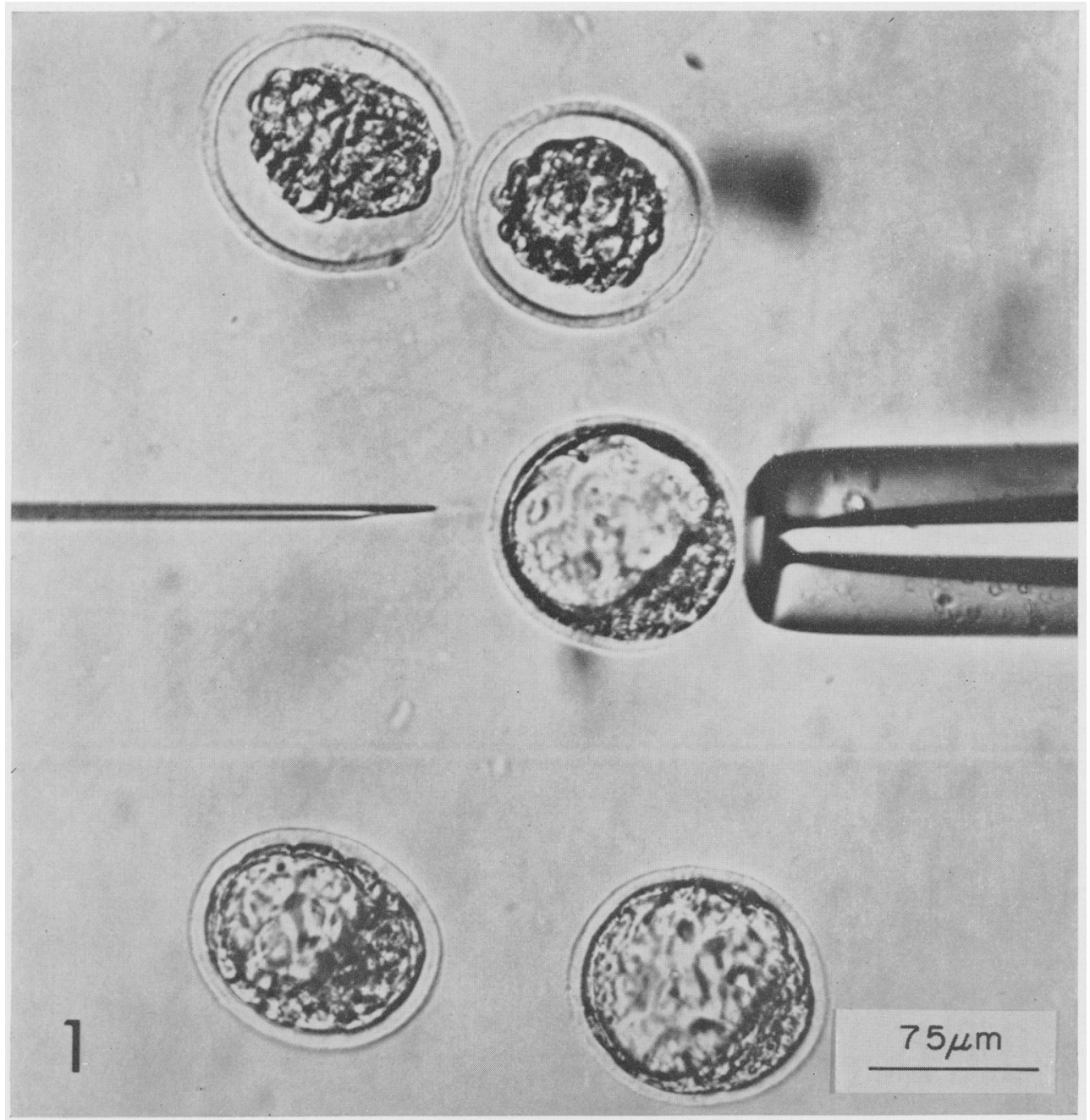

FIG. 1. The upper two mouse blastocysts have contracted following puncture. The lower two blastocysts have not been manipulated. A fifth blastocyst is immobilized by the holder pipette, whilc the puncture pipette is to the left. 


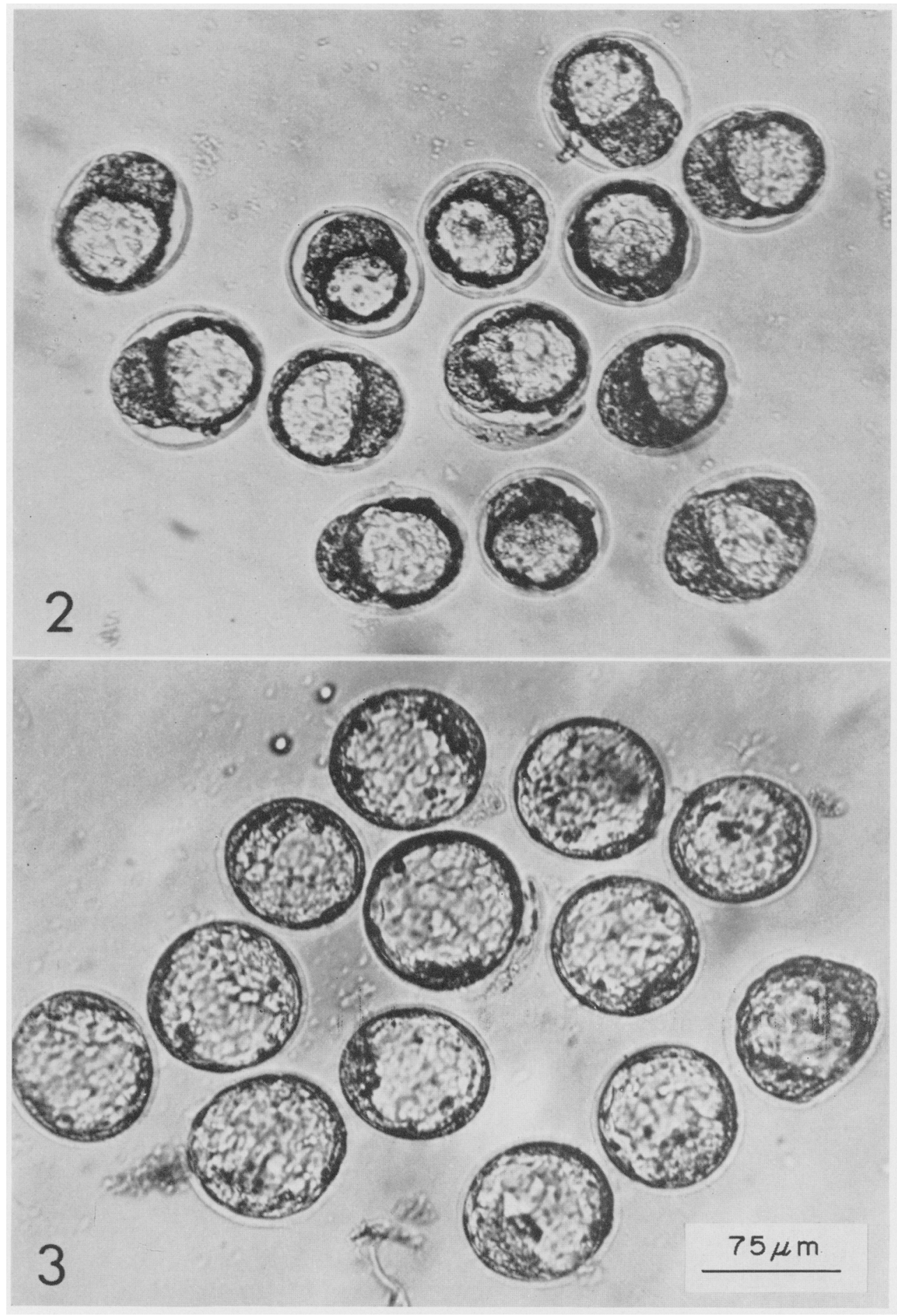

Fig. 2. Partially re-expanded blastocysts following puncture and $4 \mathrm{hr}$ incubation in Brinster's medium.

Fig. 3. The samc group of blastocysts as those pictured in Fig. 2. now fully re-expanded following $8 \mathrm{hr}$ incubation in Brinster's medium. 
can occur against an osmotic gradient (Gamow \& Daniel, 1970). Water flux would be linked to and dependent upon ionic movement.

Following puncture, blastocysts are similar in appearance to those which contract just before escape from the zona (Cole, 1967). The contractions of the latter occur over a 4- to 5-minute period while re-expansion requires 2 to $3 \mathrm{hr}$, time periods comparable to those for punctured blastocysts. In the study of Cole (1967), it was unclear whether blastocoelic fluid escaped through or between cells. It is assumed that in the punctured blastocysts fluid escaped through the traumatized area which may then have had the capacity for self repair. An alternative explanation would suggest that puncture stimulates contraction of the blastocyst with fluid egress similar to that in blastocysts experiencing spontaneous contractions.

The time sequence for re-expansion of the punctured blastocysts was also similar to that reported by Moustafa \& Brinster (1972) for blastocysts injected with cells. They noted that the blastocysts regained their original form after $4 \mathrm{hr}$ in culture, though it was not specified whether the term 'original form' meant complete or only partial expansion. Our data would suggest that only partial re-expansion occurs after $4 \mathrm{hr}$ in culture.

In view of the finding of Silagi (1963) that actinomycin does not block normal blastulation, it is not surprising that the drug failed to inhibit re-expansion of the punctured blastocyst. Puromycin, however, completely and almost immediately inhibits protein synthesis (Monesi, Molinaro, Spalletta \& Davoli, 1970). Despite this, our results show that punctured blastocysts can establish a blastocoele while incubated in puromycin. Similar results have been observed for late stage Day-3 morulae cultured under the same circumstances (C. J. Epstein and S. A. Smith, personal communication). Thus, the lack of effect of the inhibitors on blastulation is, in all likelihood, due to prior synthesis and storage of protein required for blastocoele formation.

An inhibitor which could selectively block blastulation of morulae while allowing re-expansion of punctured blastocysts might provide clues to the requirements for normal blastocoele formation.

This work was supported by Grant USPHS HD 02186-07. We thank $\mathrm{Mr}$ D. R. Akers for expert technical assistance.

\section{REFERENGES}

Brinster, R. L. (1963) A method for in vitro cultivation of mouse ova from two cell to blastocyst. Expl Cell Res. 32, 205.

CoLE, R. J. (1967) Cinemicrographic observations on the trophoblast and zona pellucida of the mouse blastocyst. F. Embryol. exp. Morph. 17, 481.

Gross, M. H. (1971) Rabbit blastocoele perfusion technique. Nature, Lond. 232, 635.

Gamow, E. \& Daniel, J. G., JR (1970) Fluid transport in the rabbit blastocyst. Wilhelm Roux Arch. EntwMech. 164, 261.

GARDNER, R. L. (1968) Mouse chimaeras obtained by the injection of cells into the blastocyst. Nature, Lond. 220, 596.

Gardner, R. L. \& Edwards, R. G. (1968) Control of the sex ratio at full term in the rabbit by transferring sexed blastocysts. Nature, Lond. 218, 346.

LiN, T. P. (1969) Microsurgery of inner cell mass of mouse blastocysts. Nature, Lond. 222, 480.

LiN, T. P. (1971) Egg micromanipulation. In: Methods in Mammalian Embryology, p. 157. Ed. J. G. Daniel, Jr. Freeman, San Francisco. 
LiN, T. P. \& MonIE, I. W. (1973) The development of mouse blastocysts injected with, or cultured in, trypan blue solution. 7. Reprod. Fert. 32, 149.

Lutwak-Mann, G., Boursnell, J. C. \& Bennett, J. P. (1960) Blastocyst-uterine relationships: uptake of radioactive ions by the early rabbit embryo and its environment. F. Reprod. Fert. 1, 169.

Monesi, V., Molinaro, M., Spalletta, E. \& Davol, G. (1970) Effect of metabolic inhibitors on macromolecular synthesis and early development in the mouse embryo. Expl Cell Res. 59, 197.

Moustafa, L. A. \& Brinster, R. L. (1972) The fate of transplanted cells in mouse blastocysts in vitro. 7. $\exp$. Zool. 181, 181.

SiLAGI, S. (1963) Some aspects of the relationship of RNA metabolism to development in normal and mutant mouse embryos cultivated in vitro. Expl Cell Res. 32, 149.

Sмiтн, M. W. (1970) Active transport in the rabbit blastocyst. Experientia, 26, 736. 